Article

\title{
Regional Patterns and Asynchronous Onset of Ice-Wedge Degradation since the Mid-20th Century in Arctic Alaska
}

\author{
Gerald V. Frost ${ }^{1, *(\mathbb{D})}$, Tracy Christopherson ${ }^{2}$, M. Torre Jorgenson ${ }^{3}$, Anna K. Liljedahl ${ }^{4}$, \\ Matthew J. Macander ${ }^{1}$ (D), Donald A. Walker ${ }^{5}$ and Aaron F. Wells ${ }^{2}$ \\ 1 ABR, Inc.-Environmental Research \& Services, P.O. Box 80410, Fairbanks, AK 99708, USA; \\ mmacander@abrinc.com \\ 2 ABR, Inc.-Environmental Research \& Services, P.O. Box 240268, Anchorage, AK 99518, USA; \\ tchristopherson@abrinc.com (T.C.); awells@abrinc.com (A.F.W.) \\ 3 Alaska Ecoscience, 2332 Cordes Way, Fairbanks, AK 99709, USA; ecoscience@alaska.net \\ 4 Water and Environmental Research Center, University of Alaska Fairbanks, Fairbanks, AK 99775, USA; \\ akliljedahl@alaska.edu \\ 5 Alaska Geobotany Center, University of Alaska Fairbanks, Fairbanks, AK 99775, USA; dawalker@alaska.edu \\ * Correspondence: jfrost@abrinc.com; Tel.: +1-907-455-6777 (ext. 142)
}

Received: 3 June 2018; Accepted: 17 August 2018; Published: 20 August 2018

\begin{abstract}
Ice-wedge polygons are widespread and conspicuous surficial expressions of ground-ice in permafrost landscapes. Thawing of ice wedges triggers differential ground subsidence, local ponding, and persistent changes to vegetation and hydrologic connectivity across the landscape. Here we characterize spatio-temporal patterns of ice-wedge degradation since circa 1950 across environmental gradients on Alaska's North Slope. We used a spectral thresholding approach validated by field observations to map flooded thaw pits in high-resolution images from circa 1950, 1982, and 2012 for 11 study areas (1577-4460 ha). The total area of flooded pits increased since 1950 at 8 of 11 study areas (median change +3.6 ha; $130.3 \%$ ). There were strong regional differences in the timing and extent of degradation; flooded pits were already extensive by 1950 on the Chukchi coastal plain (alluvial-marine deposits) and subsequent changes there indicate pit stabilization. Degradation began more recently on the central Beaufort coastal plain (eolian sand) and Arctic foothills (yedoma). Our results indicate that ice-wedge degradation in northern Alaska cannot be explained by late-20th century warmth alone. Likely mechanisms for asynchronous onset include landscape-scale differences in surficial materials and ground-ice content, regional climate gradients from west (maritime) to east (continental), and regional differences in the timing and magnitude of extreme warm summers after the Little Ice Age.
\end{abstract}

Keywords: permafrost; ice wedge; patterned ground; thermokarst; geomorphology; Arctic tundra; climate change; North Slope; Alaska

\section{Introduction}

Ice-wedge polygons are common, visually striking surficial manifestations of ground-ice in permafrost landscapes, particularly in Arctic regions with shallow permafrost and flat topography [1,2]. Ice-wedge formation is initiated by the contraction and cracking of soils during winter freezing; then, during the thaw season, the incipient cracks fill with water that freezes the following winter and becomes incorporated in permafrost [3,4]. Over centuries, wedge-shaped masses of ice enlarge through repeated seasonal cycles of cracking, thawing, and refreezing [5]. Regional- and local-scale differences in climate, landscape position, and soil physical properties produce high variability in 
polygonal landforms and rates of ice aggradation across the landscape [6]. Ice wedges can attain great size in silt-rich materials that are favorable for ground-ice aggradation, as found in yedoma landscapes of eastern Siberia and northwestern North America [7], but develop at much slower rates in sandy material.

Alaska's North Slope is underlain by continuous permafrost, and polygonal networks are nearly ubiquitous on the Arctic Coastal Plain and gently sloping, silt-rich uplands of the northern Arctic Foothills [8]. Polygonal networks create complex microtopography and strong, meter-scale contrasts in vegetation, soil hydrology, ground-ice content, and thaw-settlement potential. Polygons evolve in concert with the growth (or thaw) of underlying ice-wedges, aggradation of ice beneath polygon centers, the development of drainage networks and thermal erosion, and regional climatic change. Polygons on the North Slope overwhelmingly reflect ice wedges that have developed during Holocene time, although very large, Pleistocene-aged wedges are preserved in the subsurface and occasionally exposed in yedoma soils [9]. On the poorly drained Arctic Coastal Plain, the microtopography created by ice-wedge polygons strongly influences hydrologic flowpaths, spring runoff, and associated fluxes of dissolved nutrients [10]. This microtopography also creates important habitat features for wildlife, including breeding waterbirds of high conservation concern [11]. As a form of "patterned ground," polygonal networks possess distinctive and diagnostic surficial attributes that facilitate detection and monitoring using high-resolution remote sensing.

Numerous reports of recent ice-wedge degradation have emerged from the North American Arctic, including the North Slope [12-14], interior Alaska [15], and western Canada [16,17]. Degradation is initiated by thawing of the uppermost portions of ice wedges; the resultant subsidence forms small, flooded pits and troughs along the polygon margins that pock-mark the landscape and kill mesic-adapted vegetation [18] (Figure 1). Secondary impacts can affect large areas because pitting creates new hydrologic flowpaths that alter soil hydrology and the distribution of surface water [14]. Over time, most pits become colonized by wetland vegetation and surface water extent declines due to the development of an organic mat $[18,19]$.

Ice-wedge degradation can be triggered by surface disturbance or inundation that alters the near-surface thermal regime, as observed near industrial infrastructure [13], coastlines [20], or after tundra fires [21]. Widespread observations of recent ice-wedge degradation in undisturbed terrain, however, have implicated climatic warming as a triggering mechanism; for example, recent ice-wedge degradation near Prudhoe Bay, Alaska was triggered by unusually warm summers $[13,14,18]$. Research conducted to date indicates that most degradation has been concentrated in the last two decades, which suggests that the warm summers of the late 20th century have exceeded the range of climatic variability on the North Slope over the last several centuries.

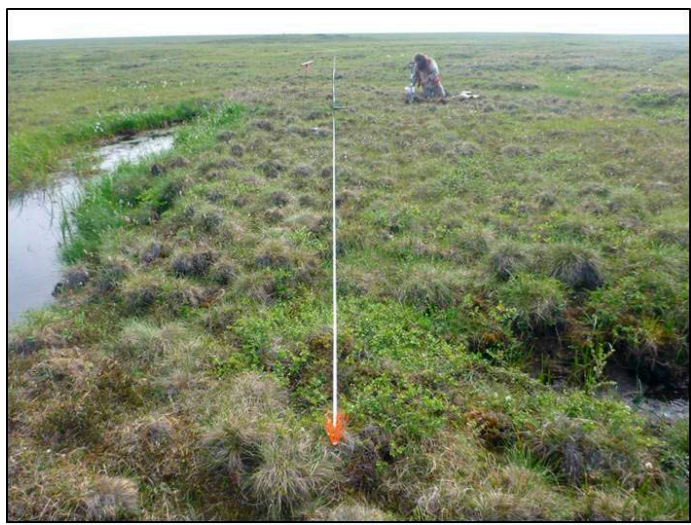

(a)

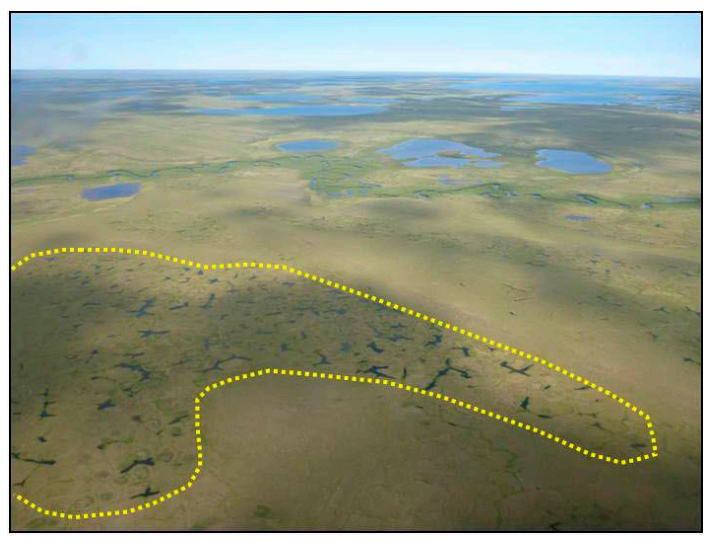

(b)

Figure 1. Ground (a) and aerial (b) views of recently formed thaw pits among high-centered polygons at Oumalik River study area, North Slope, Alaska. 
Here, we evaluate spatio-temporal patterns of ice-wedge degradation since the mid-20th century on undisturbed, residual upland surfaces in the coastal plain and foothills regions of Alaska's North Slope using high-resolution imagery for three epochs: circa 1950, 1982, and 2012. Residual surfaces have not been modified by floodplain or lake-basin development and thus comprise the oldest surficial deposits in the region, where ice wedges have developed over long periods of time and virtually all surface water is restricted to thaw pits in polygonal ground. The broad longitudinal distribution of study areas captures upland terrain with differing surficial materials, landscape histories, and ground-ice content. To support retrospective analysis of high-resolution imagery with differing spectral and spatial resolutions, we quantified the extent of thaw pits by delineating potential waterbodies using a spectral thresholding approach, and manually deleted resultant "dark" objects that did not pertain to surface water in thaw pits. Although this introduced an element of subjectivity to the analysis, we believe this approach improved precision because we were able to exploit interpretive cues related to spatial relationships and landscape context that cannot be incorporated in a fully automated approach. Our analyses were also informed by field measurements of vegetation and soils, and detailed mapping of geomorphic units and microtopography at each study area.

The overarching objectives of our study were to (1) evaluate spatio-temporal patterns of ice-wedge degradation across the understudied central and western North Slope; and (2) evaluate patterns of correspondence between the observed changes and geomorphic and climatic gradients present across the region.

\section{Materials and Methods}

\subsection{Study Area}

We analyzed changes in the spatial extent of thaw pits over time at 11 study areas (15-50 $\mathrm{km}^{2}$ each) extending from near Point Lay on the Chukchi coastal plain, eastward across the National Petroleum Reserve-Alaska (NPRA) to near the Colville River (Figure 2). The study areas are distributed across three major geomorphic units: (1) Tertiary-aged alluvial-marine deposits on the Chukchi coastal plain ("Chukchi sites"), (2) Pleistocene-aged eolian sand deposits of the central Beaufort coastal plain ("Beaufort sites") [22], and (3) Pleistocene-aged yedoma uplands of the Arctic foothills ("foothills sites") [23]. The study area locations were determined by the availability of coincident historical and modern imagery, and field plots sampled during 2010-2012. A strong climatic gradient exists across the region; summer air temperatures are higher and winter air temperatures lower in inland areas than coastal areas, although mean annual temperatures are nearly identical $\left(-11.4--11.1{ }^{\circ} \mathrm{C}\right)$ [24] (Table 1). Study areas on the coastal plain and foothills correspond to bioclimate subzones D and E of the Circumpolar Arctic Vegetation Map (CAVM), respectively [25].

Table 1. Mean annual, summer (June-August), and winter (November-March) temperature and unadjusted annual precipitation recorded at North Slope meteorological stations for 1981-2010 base period (NCDC 2017). Some stations lack observations for portions of the base period.

\begin{tabular}{ccccc}
\hline \multirow{2}{*}{ Station ${ }^{1}$} & \multicolumn{3}{c}{ Mean Temperature $\left({ }^{\circ} \mathbf{C}\right)$} & \multirow{2}{*}{ Mean Precipitation (mm) } \\
\cline { 2 - 4 } & Annual & Summer & Winter & \\
\hline Wainwright & -9.8 & +5.7 & -22.2 & 98.6 \\
Barrow & -11.4 & +3.5 & -23.1 & 116.9 \\
Umiat & -11.4 & +10.0 & -27.0 & 70.0 \\
Kuparuk & -11.1 & +6.6 & -24.9 & 101.6 \\
Deadhorse & -11.1 & +6.3 & -24.7 & 101.4 \\
\hline
\end{tabular}

${ }^{1}$ Data gaps for Wainwright (1981-1999), Umiat (1996), Kuparuk (1981-1990, 1994), and Deadhorse (1981-1985). 


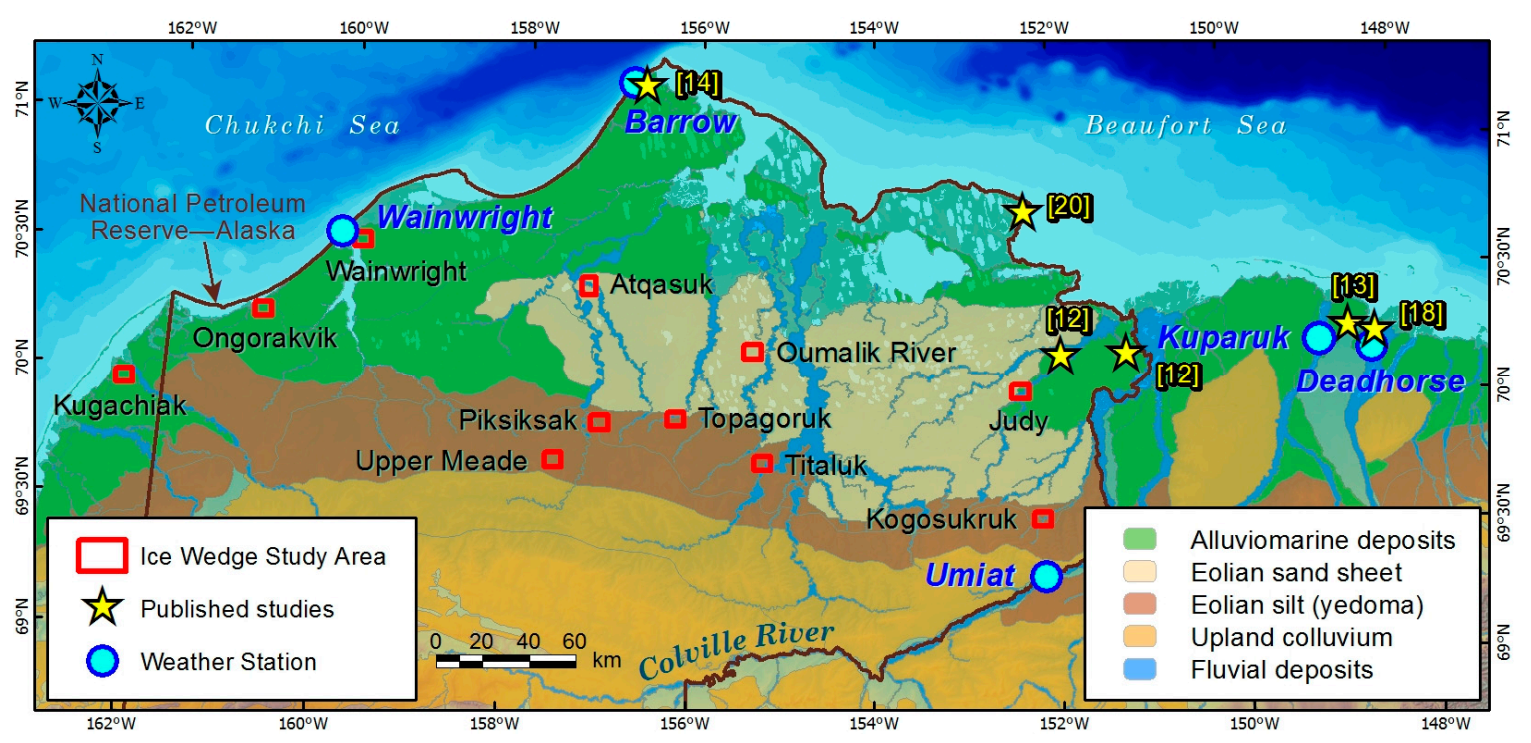

Figure 2. Locations of study sites, previously published studies (bracketed numbers), meteorological stations, and map of dominant geomorphic units adapted from Jorgenson and Grunblatt (2013) [26], North Slope, Alaska.

\subsection{Data Sources}

High-resolution imagery provides a record of thaw-pit extent for three epochs at each study area: circa 1950 (1948-1955; "early"), 1982 (1979-1985; "middle"), and 2012 (2009-2012; "late") (Table 2). The earliest imagery (1948-1949) comes from the U.S. Navy's Barrow Area Reconnaissance program and provides panchromatic aerial photography at a 1-m resolution for four study areas; similar photography collected by the U.S. Air Force in 1955 provides coverage at a 2-m resolution for the remaining seven sites. The 1979-1985 imagery comes from the Alaska High Altitude Photography (AHAP) program and provides color-infrared (CIR) aerial photography at a 0.9-1.5-m resolution. Imagery for 2009-2012 comes from several commercial multi-spectral satellites with a 2-m spatial resolution; we sought multiple summer images for the late period, but the short snow-free season, high cloud frequency, and remote locations of the study sites greatly limited the availability of useful imagery. All imagery was acquired from late June to mid-August, and imagery acquisition dates spanned less than one month for all but one site. A digital elevation model (DEM) with 2-m posting derived from Interferometric Synthetic Aperture Radar (IFSAR) covered all study areas and we used it to inform the mapping of geomorphic units and microtopography.

Table 2. Summary of study area locations and dates on which imagery was taken, North Slope, Alaska. Study areas are listed in order from west to east.

\begin{tabular}{|c|c|c|c|c|c|c|}
\hline \multirow{2}{*}{ Study Area } & \multirow{2}{*}{ Region } & \multirow{2}{*}{ Lat $\left({ }^{\circ} \mathbf{N}\right)$} & \multirow{2}{*}{ Long $\left({ }^{\circ} \mathrm{W}\right)$} & \multicolumn{3}{|c|}{ Period } \\
\hline & & & & 1950 & 1982 & $2012^{1}$ \\
\hline Kugachiak & Chukchi coastal plain & 70.0 & 162.3 & 26 Jul. 1955 & 16 Jul. 1982 & 8 Aug. 2010 (GE1) \\
\hline Ongorakvik & Chukchi coastal plain & 70.3 & 160.9 & 16 Jul. 1949 & 2 Aug. 1985 & 5 Jul. 2012 (WV2) \\
\hline Wainwright & Chukchi coastal plain & 70.6 & 159.8 & 1 Jul. 1949 & 18 Jul. 1982 & 8 Jul. 2012 (WV2) \\
\hline U. Meade & Arctic foothills & 69.8 & 157.5 & 12 Jul. 1949 & 16 Jul. 1982 & 19 Jul. 2009 (GE1) \\
\hline Atqasuk & Beaufort coastal plain & 70.5 & 157.2 & 25 Jul. 1955 & 2 Aug. 1985 & 22 Jul. 2012 (GE1) \\
\hline Piksiksak & Arctic foothills & 70.0 & 157.0 & 23 Jul. 1955 & 16 Jul. 1982 & 22 Jul. 2012 (GE1) \\
\hline Topagoruk & Arctic foothills & 70.0 & 156.2 & 23 Jul. 1955 & 16 Jul. 1982 & 9 Jul. 2010 (GE1) \\
\hline Oumalik R. & Beaufort coastal plain & 70.3 & 155.4 & 25 Jul. 1955 & 16 Jul. 1982 & 15 Jul. 2009 (GE1) \\
\hline Titaluk & Arctic foothills & 69.8 & 155.2 & 1 Aug. 1948 & 16 Jul. 1982 & 25 Jun. 2010 (WV2) \\
\hline Judy Creek & Beaufort coastal plain & 70.1 & 152.4 & 24 Jul. 1955 & 13 Jul. 1979 & 22 Jul. 2012 (GE1) \\
\hline Kogosukruk & Arctic foothills & 69.6 & 152.2 & 23 Jul. 1955 & 1 Aug. 1977 & 22 Aug. 2011 (WV2) \\
\hline
\end{tabular}

${ }^{1}$ GE1 = GeoEye-1; WV2 = WorldView-2. 


\subsection{Field Observations and Terrain Mapping}

We used field data collected in 2010-2012 at a network of plots in NPRA to support mapping of geomorphic units, polygonal surface forms, and surface water extent (Section 2.4, below). Field data were available for all but one study area (Kugachiak). At each plot, we collected data describing geomorphology, soils, vegetation, and disturbance following an ecological land survey (ELS) approach [27]; these data were useful for classifying and mapping geomorphic units, polygonal landforms, and vegetation. Geomorphic units refer to deposits of surficial materials that are the result of geomorphic, ecological, and periglacial processes and were classified according to a system developed for Alaska [28]. Surface form refers to the dominant microtopographic characteristics of ice-wedge polygons and was categorized according to Washburn (1980) [1]. We collected vegetation species-cover and structure data to classify vegetation according to the Alaska Vegetation Classification [29]. Finally, we recorded soil thaw depth, stratigraphy, and moisture regime at soil pits (40-50 cm deep). Stratigraphic data included the thickness of surface organic matter and soil physical characteristics; we also assigned a single simplified texture category (loamy, sandy, silty, or organic) to characterize the dominant soil texture and verify the geomorphic unit.

We used the field data to inform multi-parameter mapping of the study areas, including geomorphic units (alluvial-marine deposit, eolian sand, or yedoma) and polygon type (high-centered, low-centered, mixed high- and low-centered, or mixed pit-polygon complex). We digitized landscape patches by photo-interpreting the c. 2012 imagery for each study area at a scale of 1:4000 in ArcMap GIS software (ArcMap 10.5; ESRI, Redlands, CA, USA). The terrain mapping provided a means to stratify thaw pits by geomorphic unit and surface form and to assess differences in the timing and extent of thaw-pit development within and among study areas.

\subsection{Surface Water Mapping}

We first used ArcMap raster analysis tools to delineate waterbodies using the near-infrared (NIR) band in the c. 1982 and 2012 imagery; water strongly absorbs infrared radiation, whereas vegetated land reflects most incoming infrared. For each study area, we delineated all waterbodies through an iterative process in which we set a threshold NIR reflectance value in each image, and then assessed how well the threshold value distinguished water and land. After determining the best threshold value, we converted the resultant raster-based "water" pixels (or groups of adjacent pixels) to vector-based shapes. We used the same approach for the c. 1950 imagery using the single panchromatic band. Next, we used the terrain mapping to extract waterbodies that occurred in residual uplands (i.e., where surface water is restricted to thaw pits), and deleted waterbodies pertaining to lakes, ponds, drained-lake basins, and floodplains. We then visually reviewed the thaw-pit delineations and manually deleted dark shapes that were not thaw pits, such as shadowed bluffs and lake cutbanks. Finally, we summarized the spatial extent of thaw pits by geomorphic unit for each period and study area.

To evaluate the influence of interannual variability in surface water extent within a given observation period, we compared results using two images from summer 2010 (16 August; GeoEye-1) and 2011 (22 August; WorldView-2) that partially overlapped one study area (Kogosukruk). More extensive inter- and intra-annual comparisons were not feasible due to the sparse imagery archives for each of the study periods.

\section{Results}

\subsection{Field Observations and Terrain Mapping}

Field data collected in residual uplands corroborated the broad-scale geomorphic unit mapping [26]. The dominant texture of near-surface soils observed at plots usually conformed to the generalized texture of the geomorphic units: sandy soils on alluvial-marine and eolian sand sheet deposits, and silt-rich soils on yedoma (Supplementary Table S1); however, we found disjunct 
occurrences of some geomorphic units beyond the ranges evident in the regional-scale mapping. More than one upland geomorphic unit was present in two study areas; the westernmost study area (Kugachiak) included both alluvial-marine deposits and yedoma, and the easternmost study area (Kogosukruk) included both sand sheet and yedoma. The overall extent of residual uplands varied among the study areas (range 507-2825 ha; $18-84 \%$ of study area) (Table 3).

Surface forms observed in residual uplands overwhelmingly reflected high-centered, low-density polygons and mixed pits and polygons (Supplementary Table S2). Vegetation in residual uplands was primarily characterized by mesic, late-successional tundra dominated by the tussock-forming sedge Eriophorum vaginatum (Supplementary Table S3). This vegetation type was extensive and homogeneous in areas that were unaffected by ice-wedge degradation. Collectively, the biological and physical properties sampled on residual uplands were consistent with old, undisturbed settings where there has been a long, uninterrupted period of ice-wedge development. None of our field plots in residual uplands exhibited signs of recent ecological disturbance, with the exception of vegetation mortality and local ponding (e.g., "drowned" shrubs and tussocks) that are consistent with the initial and advanced phases of ice-wedge degradation [14,18].

Table 3. Summary of residual upland extent (ha) and the change in thaw-pit extent from c. 1950 to c. 2012 on an areal and percentage basis by study area, North Slope, Alaska.

\begin{tabular}{cccccc}
\hline \multirow{2}{*}{ Study Area } & Geomorphic Unit (s) & \multicolumn{2}{c}{ Residual Upland } & \multicolumn{2}{c}{$\Delta$ Pit Extent (c. 1950-2012) } \\
\cline { 3 - 5 } & & Area (ha) & $\%$ & Area (ha) & \% \\
\hline Kugachiak & alluvial-marine, yedoma & 1723.3 & $53.9 \%$ & -39.7 & $-72.5 \%$ \\
Ongorakvik & alluvial-marine & 1477.8 & $84.0 \%$ & -25.4 & $-23.5 \%$ \\
Wainwright & alluvial-marine & 750.6 & $47.6 \%$ & -11.7 & $-26.7 \%$ \\
Upper Meade & yedoma & 1200.1 & $73.7 \%$ & 0.9 & $74.8 \%$ \\
Atqasuk & eolian sand & 1412.0 & $31.7 \%$ & 1.9 & $7692.9 \%$ \\
Piksiksak & yedoma & 1550.4 & $43.4 \%$ & 4.4 & $561.9 \%$ \\
Topagoruk & yedoma & 2824.9 & $63.3 \%$ & 13.2 & $1080.6 \%$ \\
Oumalik River & eolian sand & 941.0 & $55.8 \%$ & 5.3 & $122.4 \%$ \\
Titaluk & yedoma & 507.4 & $17.8 \%$ & 11.0 & $6092.6 \%$ \\
Judy Creek & eolian sand & 1059.0 & $23.7 \%$ & 3.6 & $130.3 \%$ \\
Kogosukruk & eolian sand, yedoma & 2489.7 & $55.8 \%$ & 5.5 & $1194.3 \%$ \\
\hline
\end{tabular}

\subsection{Surface Water Mapping}

The analysis of thaw pit extent over time revealed numerous spatio-temporal patterns of thaw within and among sites. The most striking geographical difference concerned the three Chukchi sites with alluvial-marine deposits, where thaw pit extent in the early period was dramatically higher than at any of the sites further east (Figure 3, Table 3). In addition, changes over time were dramatically different in both sign and magnitude at the Chukchi sites compared to the Beaufort and foothills sites further east. At the Chukchi sites, flooded pits were most abundant in the early period (occupying $3.2-7.3 \%$ of residual deposits) and later declined (0.9-5.6\%). In contrast, the total area of thaw pits in the early period was low at all of the Beaufort and foothills sites (0-0.5\% of residual deposits), and increased markedly by the middle $(0-0.8 \%)$ and late periods $(0.2-2.2 \%)$. Even by the late period, however, the total extent of thaw pits at these sites was modest in comparison with the three Chukchi sites in nearly all cases.

In addition to the stark regional differences between the Chukchi sites and all sites farther east, spatio-temporal patterns of thaw pit development suggest differences based on geomorphic unit. Thaw pit extent was very low $(<0.5 \%)$ at the foothills (yedoma-dominated) study areas in the early period. The most dramatic increases in pit extent in the late part of the record occurred on yedoma terrain, particularly at Titaluk; here, the proportion of residual landscapes covered by thaw pits by the late period was comparable to that found at the Chukchi sites. (Figure 4). Rates of thaw pit development also increased markedly after 1982 at most of the other yedoma sites, except at Topagoruk 
where the extent of thaw pits in 1982 was similar to that present in 2010. In addition, the westernmost site-Kugachiak —encompassed both alluvial-marine deposits and yedoma; however, changes in thaw pit extent were strikingly different in the two geomorphic units. In the early period, pits were already numerous in alluvial-marine deposits ( 52.9 ha; $6.6 \%$ of deposit) but rare in yedoma (1.8 ha; $<1 \%$ of deposit) (Figure 5). Thaw pit extent peaked around 1982 in yedoma and then decreased; the development of hydrophytic vegetation (reddish signature in the 2010 imagery) is evident in many thaw pits that contained open water in 1982.

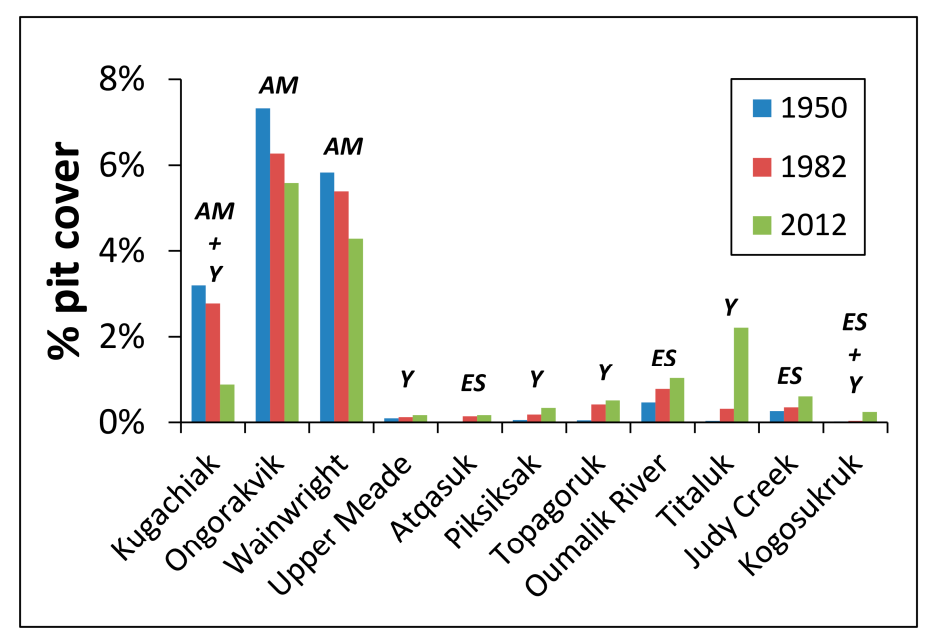

Figure 3. Percent of residual upland area covered by flooded thaw pits for the three epochs at the study areas, North Slope, Alaska. Study areas are ordered from west to east; geomorphic unit(s) at each site are indicated by abbreviations ( $\mathrm{AM}=$ alluvio-marine, $\mathrm{Y}=$ yedoma, $\mathrm{ES}=$ eolian sand).

Changes in thaw pit extent were variable at the Beaufort sites dominated by eolian sand. Thaw pits occupied a very low percentage of residual landscapes at most sites in the early period $(0-0.5 \%$ of deposit), particularly at Atqasuk where virtually no pits were present. Pit extent increased markedly by the late period at all four sites with eolian sand on a percent basis; however, pits still occupied a very low proportion of residual deposits $(<1 \%)$. Rates of thaw-pit development were highest from c. 1950 to c. 1982 at Atqasuk and Ouamalik River, but higher after c. 1982 Judy Creek, the easternmost site.

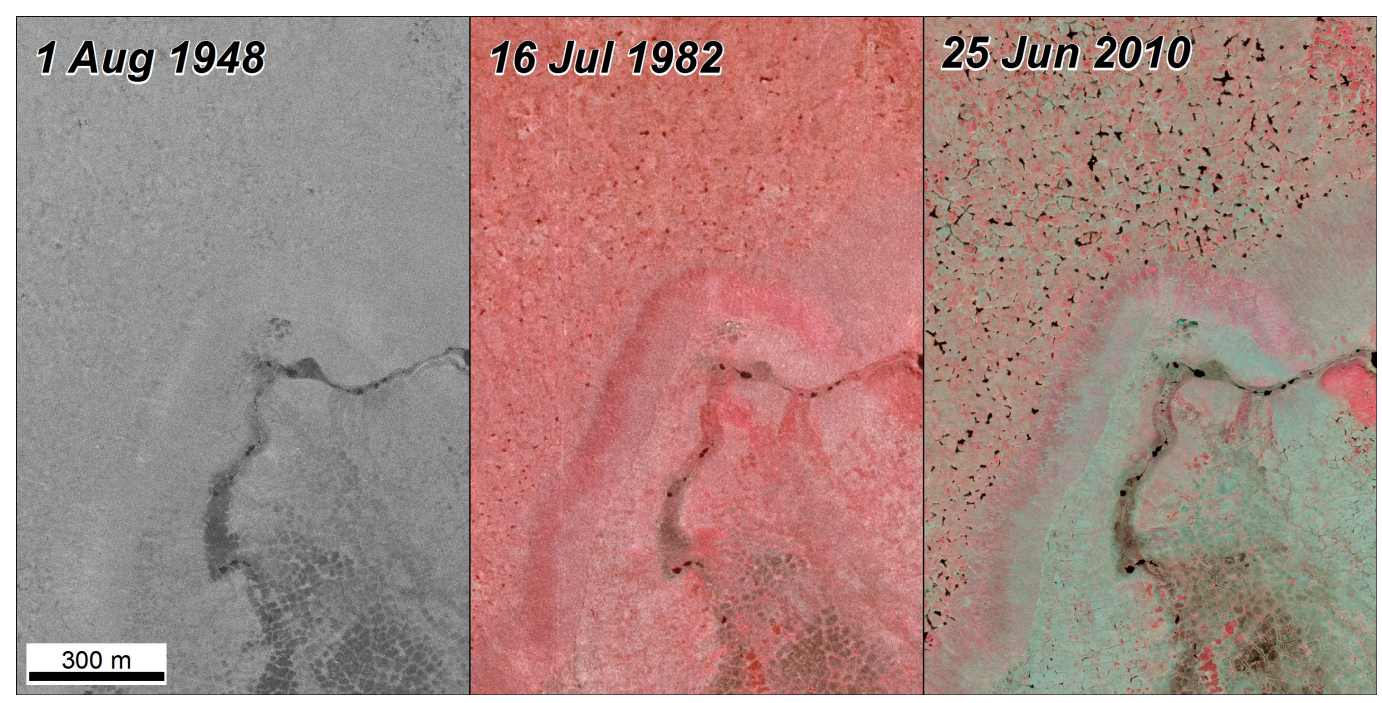

Figure 4. Recent onset of ice-wedge degradation in yedoma uplands at Titaluk site in the Arctic foothills, 1948-2010, North Slope, Alaska. 


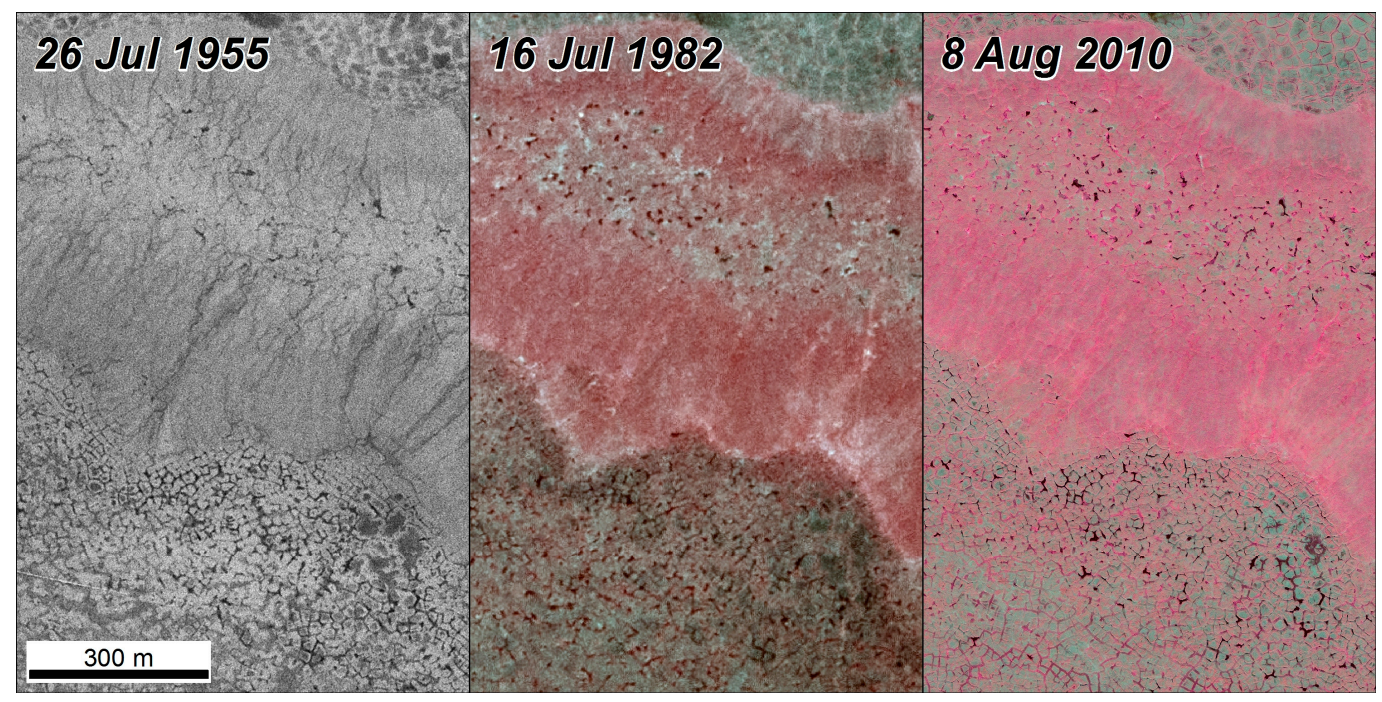

Figure 5. Thaw pit development at Kugachiak site on yedoma uplands (top half of images) and alluvial-marine deposits (bottom) of the Chukchi coastal plain, 1955-2010, North Slope, Alaska.

Comparison of surface water extent from August 2010 and 2011 for a portion of Kogosukruk indicates moderate differences in extent that presumably arose from interannual differences in precipitation and evapotransipiration. Mapping derived from overlapping 2010 and 2011 imagery indicated 3.0 ha and 2.5 ha of surface water associated with thaw pits, respectively ( $22.4 \%$ difference).

\section{Discussion}

\subsection{Mechanisms for Asynchronous Onset}

Our time-series analysis indicates strong regional contrasts in the timing and magnitude of ice-wedge degradation since the mid-20th century on the North Slope. The recent onset of ice-wedge degradation that we observed at most of the Beaufort and foothills sites was contemporaneous with that observed by others farther east near the Colville River Delta and Deadhorse, where field studies provide strong evidence that thawing was initiated by extremely warm summers during the 1990s and early 2000s [12-14,19]. These warm summers are prominent in instrumental records from stations across the North Slope (Figure 6), suggesting that ice-wedge degradation at most of the Beaufort and foothills sites probably began by the same mechanism. Degradation of ice wedges at the Chukchi sites in the west, however, began at least five decades earlier (pre-1950) and thus cannot be explained by extreme warmth in the late 20th-century. This raises the question of whether the asynchronous onset resulted from regional climatic variability, different landscape histories, differences in surficial materials that affected their susceptibility to ice-wedge degradation, or interactions between these factors.

When did ice-wedge degradation begin on the western North Slope, and what was the proximal cause? Our surface water analysis indicates that polygonal networks at the Chukchi sites were already in the initial degradation phase proposed by Liljedahl et al. (2016) [14] by about 1950 . This initial degradation phase is thought to persist for 15-40 years before progressing to an advanced degradation phase, in which surface water declines due to vegetation succession and increased hydrologic connectivity among polygon troughs [18]. We therefore believe that ice-wedge degradation began at the Chukchi sites no earlier than 1900. This timing aligns with a warm period during the 1930s and 1940s that is evident in station data at Barrow, as was observed in the eastern Beaufort Sea region [30] and elsewhere in the Arctic [31,32]. This warm period occurred not long after the end of the Little Ice Age (LIA) in the mid-late 19th century, which marked a pronounced change in climate regime across the North Slope. Collectively, 20th century warm periods on the North Slope display close correspondence with positive phases of the Pacific Decadal Oscillation (PDO) index, which favor 
warm temperatures in Arctic Alaska [33]. The period of predominantly positive PDO indices in the early 20th century, and especially from 1930-1945 (Figure 6), suggests that the combination of secular warming following the LIA, and synoptic cycles of the PDO initiated ice-wedge degradation first on the Chukchi coastal plain. The earlier onset of degradation at the Chukchi sites may also relate to the more maritime climate regime near the coast relative to the drier continental regime farther east; however, this gradient is not strong in climatic reanalysis datasets [34] and is also difficult to resolve directly due to the sparse instrumental record in the region.

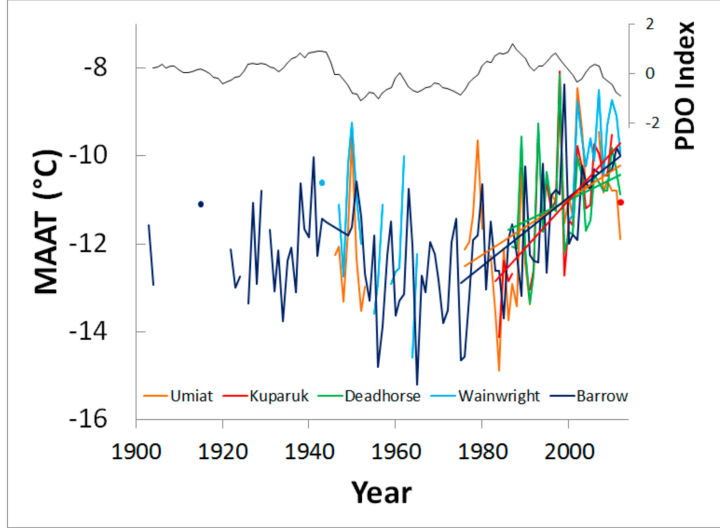

(a)

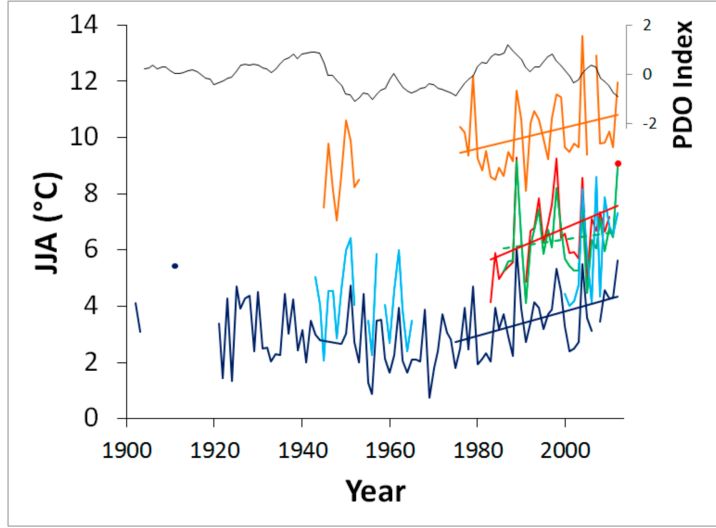

(b)

Figure 6. Mean annual air temperature (MAAT; a) and mean June-August air temperature (JJA; b) records for North Slope meteorological stations, 1901-2012. Each plot also displays the 5-year running average of the Pacific Decadal Oscillation Index. Discontinuities exist in the record for most stations; circles denote isolated years with data. Trendlines indicate statistically significant linear trends $(p<0.05)$ recorded at stations since 1975 .

The climatic thresholds required to initiate ice-wedge degradation are likely to vary at localto regional scales, depending on precipitation regime, surface wetness, vegetation productivity, thickness of insulating organic matter, ground-ice content, and the thermal conductivity of surficial materials [35]. Of particular relevance to ice-wedge degradation are differences in the thickness and ice content of the uppermost permafrost, which protects long-lived ice wedges in deeper permafrost from stochastic, extreme events [36]. Differences in the properties of the uppermost permafrost in different residual deposits, and regional differences in the magnitude of extreme warm summers on the North Slope, offer plausible explanations for the asynchronous onset of ice wedge degradation that we observed in the region. Regardless of the timing of ice-wedge degradation, however, the sheer abundance of thaw pits present at the three Chukchi sites indicates that the alluvial-marine deposits of the Chukchi coastal plain were especially vulnerable to thermokarst processes. For example, Farquharson et al. [37] mapped the spatial extent of thermokarst landforms on the North Slope, including degraded polygonal ground, and found that the total area affected by thermokarst on alluvial-marine deposits in northwest Alaska exceeds that found on the eolian deposits. Alluvial-marine deposits of the Chukchi coastal plain are also older (Pliocene) than the Pleistocene eolian deposits prevalent to the east, although given the predominantly sandy texture of Chukchi residual deposits, it is not clear that their greater age would translate into larger volumes of wedge-ice in modern times.

\subsection{Sources of Uncertainty}

Surface water's utility as an indicator of underlying geomorphic conditions, and its distinctive spectral characteristic make it an attractive target for remote-sensing studies in dynamic permafrost regions. Analysis of thermokarst processes based on surface water extent is sensitive, however, to several confounding factors, including seasonal variation in water levels, interannual 
variation in precipitation, and topographic effects on water retention (flats vs. slopes) [38,39]. Seasonally, water levels and extent on the North Slope peak after spring snowmelt, draw down in midsummer due to evapotranspiration and thawing of the active-layer, and then usually increase in late summer due to rainfall and reduced evapotranspiration [40-42]. For example, in flat terrain with mixed low- and high-centered polygons at Prudhoe Bay, Koch et al. [43] estimated that surface water temporarily covered $49 \%$ of the land during snowmelt, but only $5 \%$ during midsummer (primarily in thermokarst troughs). Thermokarst pits and troughs tend to have steep banks, such that incremental changes in water depth have limited effects on surface water extent; for example, Jorgenson and others [18] estimated that the effects of seasonal and interannual variation in water levels are small $(\approx 1 \%$ of area) when using midsummer (i.e., July) imagery. Comparison of surface water extent from August 2010 and 2011 for a portion of Kogosukruk indicated much larger differences. We attribute much of the difference to the presence of low-centered polygons in the area of overlap, where small differences in water depth can lead to relatively large differences in water extent. Despite this variability, however, surface water extent was so low in 1955 and 1977 (0.1 and 0.2 ha in area of overlap, respectively) that we do not believe interannual variability can explain the overall spatio-temporal change patterns evident at that site. We caution, however, that interannual and seasonal variability are likely to be important at sites with very low surface water extents across all epochs (e.g., Atqasuk).

In our study, imagery for the 1950 observation period came from July 1-August 1, with all but three confined to 23 July-1 August (Table 2). For the 1982 period, imagery came from 13 July-2 August. The 2010 period had the widest range of dates, spanning 25 Jun-22 August. There was, however, no systematic bias for any of the three periods toward early or late acquisition dates, so the overall trends of increasing thaw pit extent at eastern sites and decreasing extent at Chukchi sites are not readily explained by bias in seasonal timing of imagery. Macander et al. (2015) [44] produced a snow persistence map for northwest Alaska that provides median spring snow-off dates for each study area at a 30-m resolution using Landsat TM/ETM+ from 1985-2011. The median snowmelt dates for the eleven sites all fall within a 14-day period (24 May-7 June) and provide confidence that the acquisition dates of imagery used in our analysis are appropriate for comparisons both within, and among sites. For example, all of the images we used were acquired at least 31 days after the median snowmelt date for a given site. This includes the imagery with the earliest seasonal timing (25 June, 2010 at Titaluk, the only image not acquired in July or August).

Under what conditions is surface water extent most likely to provide an accurate record of spatio-temporal changes in the Arctic's expansive polygonal landscapes? While mapping of waterbodies provides a practical means of assessing ice-wedge degradation over time, it is an imperfect measure because vegetation recovery can reduce surface water extent over time, troughs can degrade without filling with water (particularly on slopes), and water can be redistributed through channel integration and microtopographic changes. Our primary objective, however, was to track the onset of ice-wedge degradation across old (i.e., pre-Holocene), residual surfaces that have experienced long periods of syngenetic permafrost development and where an abrupt increase in surface water is an unequivocal indicator of thermokarst processes. Although the topographic relief of the North Slope is generally slight, some foothills study areas have polygonized hillslopes where ice-wedge degradation is unlikely to create flooded conditions; thus, our approach probably underestimated the extent of ice-wedge degradation in some cases (e.g., Titaluk; Figure 5). In addition, we omitted floodplains and drained lake basins from analysis because these areas hold a wide variety of polygonal surface forms, including extensive low-centered polygons, which greatly complicates multi-temporal comparison of surface water extent. The strong sorting of sediment and epigenetic nature of permafrost development in basins also causes high local variability in rates of ground-ice development and vulnerability to thermokarst [6]. The emergence of topographic analyses using ground-based and airborne LiDAR hold great promise for future change-detection studies across a wide variety of terrain types [21,45-47]. For the time being, however, retrospective assessments of landscape change are likely to remain reliant on panchromatic and multi-spectral optical data due to the long period-of-record for these data sources. 
A final source of uncertainty concerns imagery quality. The approach that we used to map surface water rested on the assumption that "water is dark," with lower reflectance in high-resolution imagery than other surface features. The spatial and spectral resolutions of the imagery collection vary considerably for the three observational periods; the c. 1950 imagery is panchromatic, while the imagery for the later periods is multi-spectral and includes a NIR band. These differences raise the question of whether the changes we observed resulted from artifacts related to image properties, rather than actual changes on the ground. Although our workflow for delineating thaw pits began with spectral thresholding of raster data, the thresholds were set independently for each image using visual photo-interpretation, and the conversion of the resultant raster objects to vector-based map units allowed us to carefully screen the results. Using photo-interpretation we deleted "water" map units related to local settings with low reflectance (e.g., shadowed terrain), small waterbodies that were not associated with thermokarst pits, and image artifacts. The visual screening step also permitted us to apply a high spectral threshold that included all potential waterbodies.

\subsection{Implications for North Slope Ecosystems}

All of the study areas analyzed here have experienced ice-wedge degradation to some degree since the mid-20th century. Dramatic contrasts were evident in the abundance of flooded thaw pits and troughs as well as their timing of appearance on the landscape. These contrasts likely have significant implications for vegetation succession and landscape evolution in the coming decades. The three western study areas on the Chukchi coastal plain all had abundant thaw pits by the mid-20th century, and changes since then generally reflect a shift from open surface water to increased cover of hydrophytic vegetation. This is consistent with successional sequences observed in polygonal landscapes elsewhere on the North Slope [18,19]. Although the areal extent of individual thaw features is small, the cumulative area of these features is large enough that vegetation mortality and ponding in early stages, and vegetation succession and reduction in surface wetness in later stages could influence landscape "greenness" observed by satellites in the form of the Normalized Difference Vegetation Index (NDVI) [48].

Although a period of widespread and rapid ice-wedge degradation must have occurred at the Chukchi sites in the first half of the 20th century, we did not observe any instances in which degrading networks of ice-wedge polygons coalesced into thaw-lake basins (i.e., contiguous areas of thermokarst). Thus, the historical perspective we provide in this study corroborates observational records and conceptual frameworks articulated by previous authors [19], and indicates that the potential for large-scale landscape collapse and persistent increases in surface water extent after ice-wedge degradation are unlikely. Nonetheless, even though the mapped extent of flooded thaw pits was generally small compared to the total extent of residual deposits at most study sites, the microtopographic changes associated with differential thaw subsidence dramatically alters landscape hydrologic connectivity and the soil moisture regime far beyond the footprints of the thaw pits themselves. Many residual landscapes of the Chukchi coastal plain are pock-marked by extensive ice-wedge degradation and, although extensive areas of late-successional tussock tundra remain intact, the degraded polygonal networks form complex landscape mosaics of mesic, wet, and flooded microsites. Such mosaic landscapes may foretell future changes to residual landscapes elsewhere on the North Slope that currently support much more homogeneous vegetation, surficial features, and habitat conditions.

\section{Conclusions}

Using a retrospective remote-sensing approach, we found that ice-wedge degradation has driven increases in surface water extent since 1950 at 8 of 11 study areas spanning Alaska's western and central North Slope (median change $+130.3 \%$ ). Although the recent, rapid increases in waterbody extent observed at several sites corroborate previous findings that ice-wedge degradation in the region was initiated by warm summers in the late 20th century, our finding that polygonal landscapes 
on the Chukchi coastal plain were already extensively degraded by 1950 lead us to conclude that transformation of polygonal networks in cold continuous permafrost is not solely constrained to the last few decades in northern Alaska, and likely elsewhere in the Arctic.

The use of surface water extent as a remotely sensed metric of permafrost dynamics has several strengths, mainly stemming from the distinctive spectral properties of surface water and its value as an indicator of underlying geomorphic conditions. We caution the remote sensing community, however, that confounding factors related to the specific geomorphic settings under study (e.g., low-versus high-centered polygons), and the potential influence of seasonal and inter-annual variability on surface water must be carefully considered. The multi-temporal, spectral thresholding approach presented here is best suited for flat landscapes with continuous permafrost, and requires that imagery come from the narrow, midsummer seasonal period.

Our findings provide context for interpreting and predicting the dynamics, climatic thresholds, and impacts of ice-wedge degradation in continuous permafrost of Alaska and elsewhere in the Arctic. While it has become clear that degradation of Holocene-aged ice wedges is underway in many parts of the Arctic, the broader ecosystem implications of these landscape changes remain poorly understood, with a range of potential consequences to ecosystem structure and function, as well as landscape sensitivities to industrial activity on the North Slope. Ice-wedge degradation appears to represent a rapid and conspicuous landscape response to extreme warm summers. Although successional processes tend to promote rapid vegetation recovery and paludification of thaw pits, the changes to landscape microtopography, soil hydrology, and hydrologic connectivity represent persistent impacts that are not reversible except on millennial timescales. Mismatches in the timing of ice-wedge degradation highlight the importance of landscape-scale differences in surficial geomorphology and regional climatic variability, and their role in modulating the response of Arctic environments to climate warming.

Supplementary Materials: The following are available online at http:/ /www.mdpi.com/2072-4292/10/8/1312/s1, Table S1: Description of geomorphic units in the North Slope study areas. Modified from Kreig and Reger (1982) [28], Table S2: Description of surface forms in the North Slope study areas. Modified from Washburn (1980) [1], and Table S3: Description of vegetation types in the North Slope study areas. Modified from Viereck et al. (1992) [29].

Author Contributions: G.V.F. conceived and designed the study and wrote the paper with contributions from D.A.W., A.K.L., M.T.J., A.F.W. and T.C. A.F.W. and M.J.M. led the field studies.

Funding: This research was funded by Shell Exploration \& Production Company as part of their multi-year Onshore Environmental Studies Program in northern Alaska.

Acknowledgments: We thank the many field biologists at ABR, Inc. who collected ground data in NPRA during 2010-2012, foremost our colleague Erin K. Johnson, in whose memory we dedicate this work. We also thank Erling Westlien and Michael Macrander at Shell Exploration \& Production Company.

Conflicts of Interest: The funding sponsors had no role in the design of this study; in the collection, analyses, or interpretation of the data; in the writing of the manuscript; or in the decision to publish the results.

\section{References}

1. Washburn, A.L. Geocryology: A Survey of Periglacial Processes and Environments; John Wiley \& Sons, Inc.: Hoboken, NJ, USA, 1980.

2. French, H.M. The Periglacial Environment; John Wiley \& Sons, Ltd: Chichester, UK, 2007.

3. De Koven Leffingwell, E. The Canning River Region, Northern Alaska; Government Printing Office: Washington, DC, USA, 1919.

4. Lachenbruch, A.H. Mechanics of Thermal Contraction Cracks and Ice-Wedge Polygons in Permafrost; The Waverly Press: Baltimore, MD, USA, 1962.

5. Romanovskii, N. Formation of Ice Wedges-Polygonal Patterns; Nauka: Novosibirsk, Russia, 1977.

6. Jorgenson, M.T.; Shur, Y. Evolution of lakes and basins in northern Alaska and discussion of the thaw lake cycle. J. Geophys. Res. 2007, 112. [CrossRef] 
7. Schirrmeister, L.; Froese, D.; Tumskoy, V.; Wetterich, S. Yedoma: Late Pleistocene ice-rich syngenetic permafrost of Beringia. In Encyclopedia of Quaternary Science, 2nd ed.; Elias, S.A., Mock, C.J., Eds.; Elsevier: Amsterdam, The Netherlands, 2012; pp. 542-552.

8. Gallant, A.L.; Binnian, E.F.; Omernik, J.M.; Shasby, M.B. Ecoregions of Alaska; United States Government Printing Office: Washington, DC, USA, 1995.

9. Kanevskiy, M.; Shur, Y.; Fortier, D.; Jorgenson, M.T.; Stephani, E. Cryostratigraphy of late Pleistocene syngenetic permafrost (yedoma) in northern Alaska, Itkillik River exposure. Quat. Res. 2011, 75, 584-596. [CrossRef]

10. Liljedahl, A.K.; Hinzman, L.D.; Schulla, J. Ice-wedge polygon type controls low-gradient watershed-scale hydrology. In Proceedings of the Tenth International Conference on Permafrost, Salekhard, Russia, 25-29 June 2012; pp. 231-236.

11. Anderson, B.A.; Cooper, B.A. Distribution and Abundance of Spectacled Eiders in the Kuparuk and Milne Point Oilfields, Alaska, 1993; Alaska Biological Research, Inc.: Fairbanks, AK, USA, 1994.

12. Jorgenson, M.T.; Shur, Y.L.; Pullman, E.R. Abrupt increase in permafrost degradation in Arctic Alaska. Geophys. Res. Lett. 2006, 33. [CrossRef]

13. Raynolds, M.K.; Walker, D.A.; Ambrosius, K.J.; Brown, J.; Everett, K.R.; Kanevskiy, M.; Kofinas, G.P.; Romanovsky, V.E.; Shur, Y.; Webber, P.J. Cumulative geoecological effects of 62 years of infrastructure and climate change in ice-rich permafrost landscapes, Prudhoe Bay Oilfield, Alaska. Glob. Chang. Biol. 2014, 20, 1211-1224. [CrossRef] [PubMed]

14. Liljedahl, A.K.; Boike, J.; Daanen, R.P.; Fedorov, A.N.; Frost, G.V.; Grosse, G.; Hinzman, L.D.; Iijma, Y.; Jorgenson, J.C.; Matveyeva, N.; et al. Pan-Arctic ice-wedge degradation in warming permafrost and its influence on tundra hydrology. Nat. Geosci. 2016, 9, 312-318. [CrossRef]

15. Necsoiu, M.; Dinwiddie, C.L.; Walter, G.R.; Larsen, A.; Stothoff, S.A. Multi-temporal image analysis of historical aerial photographs and recent satellite imagery reveals evolution of water body surface area and polygonal terrain morphology in Kobuk Valley National Park, Alaska. Environ. Res. Lett. 2013, 8. [CrossRef]

16. Kokelj, S.V.; Lantz, T.C.; Wolfe, S.A.; Kanigan, J.C.; Morse, P.D.; Coutts, R.; Molina-Giraldo, N.; Burn, C.R. Distribution and activity of ice wedges across the forest-tundra transition, western Arctic Canada: Ice wedges across tree line. J. Geophys. Res. Earth Surf. 2014, 119, 2032-2047. [CrossRef]

17. Wolter, J.; Lantuit, H.; Fritz, M.; Macias-Fauria, M.; Myers-Smith, I.; Herzschuh, U. Vegetation composition and shrub extent on the Yukon coast, Canada, are strongly linked to ice-wedge polygon degradation. Polar Res. 2016, 35. [CrossRef]

18. Jorgenson, M.T.; Kanevskiy, M.; Shur, Y.; Moskalenko, N.; Brown, D.R.N.; Wickland, K.; Striegl, R.; Koch, J. Role of ground ice dynamics and ecological feedbacks in recent ice wedge degradation and stabilization. J. Geophys. Res. Earth Surf. 2015, 120. [CrossRef]

19. Kanevskiy, M.; Shur, Y.; Jorgenson, T.; Brown, D.R.N.; Moskalenko, N.; Brown, J.; Walker, D.A.; Raynolds, M.K.; Buchhorn, M. Degradation and stabilization of ice wedges: Implications for assessing risk of thermokarst in northern Alaska. Geomorphology 2017, 297, 20-42. [CrossRef]

20. Tape, K.D.; Flint, P.L.; Meixell, B.W.; Gaglioti, B.V. Inundation, sedimentation, and subsidence creates goose habitat along the Arctic coast of Alaska. Environ. Res. Lett. 2013, 8. [CrossRef]

21. Jones, B.M.; Grosse, G.; Arp, C.D.; Miller, E.; Liu, L.; Hayes, D.J.; Larsen, C.F. Recent Arctic tundra fire initiates widespread thermokarst development. Sci. Rep. 2015, 5. [CrossRef] [PubMed]

22. Carter, L.D. A Pleistocene sand sea on the Alaskan Arctic coastal plain. Science 1981, 211, 381-383. [CrossRef] [PubMed]

23. Williams, J.R. Engineering-Geologic Maps of Northern Alaska, Wainwright Quadrangle; U.S. Geological Survey: Menlo Park, CA, USA, 1983.

24. Haugen, R.K.; Brown, J. Coastal-inland distributions of summer air temperature and precipitation in northern Alaska. Arct. Alp. Res. 1980, 12, 403-412. [CrossRef]

25. Circumpolar arctic vegetation map (1:7,500,000 scale), Conservation of Arctic Flora and Fauna (CAFF) Map No. 1. 2003. Available online: https:/ / www.geobotany.uaf.edu/cavm/ (accessed on 3 June 2018). 
26. Jorgenson, M.T.; Grunblatt, J. Landscape-Level Ecological Mapping of Northern Alaska and Field Site Photography; U.S. Fish and Wildlife Service: Fairbanks, AK, USA, 2013.

27. Jorgenson, M.T.; Roth, J.E.; Miller, P.F.; Macander, M.J.; Duffy, M.S.; Wells, A.F.; Frost, G.V.; Pullman, E.R. An Ecological Land Survey and Landcover Map of the Arctic Network; U.S. Department of the Interior: Fort Collins, CO, USA, 2009.

28. Kreig, R.A.; Reger, R.D. Air-Photo Analysis and Summary of Land-Form Soil Properties Along the Route of the Trans-Alaska Pipeline System; Alaska Division of Geological and Geophysical Surveys: Fairbanks, AK, USA, 1982.

29. Viereck, L.A.; Dyrness, C.T.; Batten, A.R.; Wenzlick, K.J. The Alaska Vegetation Classification; U.S. Department of Agriculture, Forest Service, Pacific Northwest Research Station: Portland, OR, USA, 1992.

30. Burn, C.R.; Zhang, Y. Permafrost and climate change at Herschel Island (Qikiqtaruq), Yukon Territory, Canada. J. Geophys. Res. Earth Surf. 2009, 114. [CrossRef]

31. Johannessen, O.M.; Bengtsson, L.; Miles, M.W.; Kuzmina, S.I.; Semenov, V.A.; Alekseev, G.V.; Nagurnyi, A.P.; Zakharov, V.F.; Bobylev, L.P.; Pettersson, L.H.; et al. Arctic climate change: Observed and modelled temperature and sea-ice variability. Tellus A Dyn. Meteorol. Oceanogr. 2004, 56, 328-341. [CrossRef]

32. Harris, I.; Jones, P.D.; Osborn, T.J.; Lister, D.H. Updated high-resolution grids of monthly climatic observations-The CRU TS3.10 Dataset. Int. J. Climatol. 2013, 34, 623-642. [CrossRef]

33. Mantua, N.J.; Hare, S.R.; Zhang, Y.; Wallace, J.M.; Francis, R.C.A. Pacific interdecadal climate oscillation with impacts on salmon production. Bull. Am. Meteorol. Soc. 1997, 78, 1069-1079. [CrossRef]

34. Cai, L.; Alexeev, V.A.; Arp, C.D.; Jones, B.M.; Liljedahl, A.K.; Gädeke, A. The Polar WRF downscaled historical and projected twenty-first century climate for the coast and foothills of Arctic Alaska. Front. Earth Sci. 2018, 5. [CrossRef]

35. Shur, Y.L.; Jorgenson, M.T. Patterns of permafrost formation and degradation in relation to climate and ecosystems. Permafr. Periglac. Process. 2007, 18, 7-19. [CrossRef]

36. Shur, Y.; Hinkel, K.M.; Nelson, F.E. The transient layer: Implications for geocryology and climate-change science. Permafr. Periglac. Process. 2005, 16, 5-17. [CrossRef]

37. Farquharson, L.M.; Mann, D.H.; Grosse, G.; Jones, B.M.; Romanovsky, V.E. Spatial distribution of thermokarst terrain in Arctic Alaska. Geomorphology 2016, 273, 116-133. [CrossRef]

38. Jorgenson, M.T.; Grosse, G. Remote sensing of landscape change in permafrost regions. Permafr. Periglac. Process. 2016, 27, 324-338. [CrossRef]

39. Bartsch, A.; Höfler, A.; Kroisleitner, C.; Trofaier, A. Land cover mapping in northern high latitude permafrost regions with satellite data: Achievements and remaining challenges. Remote Sens. 2016, 8, 979. [CrossRef]

40. Liljedahl, A.K.; Hinzman, L.D.; Harazono, Y.; Zona, D.; Tweedie, C.E.; Hollister, R.D.; Engstrom, R.; Oechel, W.C. Nonlinear controls on evapotranspiration in arctic coastal wetlands. Biogeosciences 2011, 8, 3375-3389. [CrossRef]

41. Koch, J.C. Lateral and subsurface flows impact arctic coastal plain lake water budgets. Hydrol. Process. 2016, 30, 3918-3931. [CrossRef]

42. Liljedahl, A.K.; Hinzman, L.D.; Kane, D.L.; Oechel, W.C.; Tweedie, C.E.; Zona, D. Tundra water budget and implications of precipitation underestimation. Water Resour. Res. 2017, 53, 6472-6486. [CrossRef] [PubMed]

43. Koch, J.C.; Jorgenson, M.T.; Wickland, K.P.; Kanevskiy, M.; Striegl, R.G. Ice wedge degradation and stabilization impacts water budgets and nutrient cycling in Arctic thaw ponds. J. Geophys. Res. Biogeosci. 2018. [CrossRef]

44. Macander, M.J.; Swingley, C.S.; Joly, K.; Raynolds, M.K. Landsat-based snow persistence map for northwest Alaska. Remote Sens. Environ. 2015, 163, 23-31. [CrossRef]

45. Günther, F.; Overduin, P.P.; Sandakov, A.V.; Grosse, G.; Grigoriev, M.N. Short-and long-term thermo-erosion of ice-rich permafrost coasts in the Laptev Sea region. Biogeosciences 2013, 10, 4297-4318. [CrossRef]

46. Jones, B.M.; Stoker, J.M.; Gibbs, A.E.; Grosse, G.; Romanovsky, V.E.; Douglas, T.A.; Kinsman, N.E.M.; Richmond, B.M. Quantifying landscape change in an arctic coastal lowland using repeat airborne LiDAR. Environ. Res. Lett. 2013, 8. [CrossRef] 
47. Whitley, M.A.; Frost, G.V.; Jorgenson, M.T.; Macander, M.J.; Maio, C.V.; Winder, S.G. Assessment of LiDAR and spectral techniques for high-resolution mapping of sporadic permafrost on the Yukon-Kuskokwim Delta, Alaska. Remote Sens. 2018, 10, 258. [CrossRef]

48. Lara, M.J.; Nitze, I.; Grosse, G.; Martin, P.; McGuire, A.D. Reduced arctic tundra productivity linked with landform and climate change interactions. Sci. Rep. 2018, 8. [CrossRef] [PubMed]

(C) 2018 by the authors. Licensee MDPI, Basel, Switzerland. This article is an open access article distributed under the terms and conditions of the Creative Commons Attribution (CC BY) license (http:/ / creativecommons.org/licenses/by/4.0/). 